\title{
Research and Practice of School Enterprise Cooperation Training Orders after Sale Repair Engineers
}

\author{
Jiangyong Xing \\ Nanjing Communications Institute of Technology \\ Nanjing China \\ E-mail:13851680037@163.com
}

\author{
Kaiju Zhang \\ Nanjing Communications Institute of Technology \\ Nanjing China \\ E-mail:kjz@126.com
}

\begin{abstract}
The comprehensive construction of well-off society, the living standard of urban and rural residents in China continue to improve, various household appliances, information consumption product benefit thousands of households. New product information consumption of various energy-saving appliances, promotes unceasingly, put forward higher requirement for the home appliance repair service industry and information consumption demand and service level. Cooperation between universities and enterprises orders training appliance repair customer service engineer, creating a new mode for cultivating high skill talents of China's household electrical appliance repair services and information consumption.
\end{abstract}

Keywords- school enterprise cooperation; order training; after sale Repair Engineer; information consumption

\section{INTRODUCTION}

To expand domestic demand and consumption, the state issued home appliances to the countryside, with old change new, buy energy-efficient appliances subsidies and a series of preferential policies. Recently the State Council issued the "opinions on promoting information consumption to expand domestic demand". In the current resident consumption upgrading of our country, industrialization, informationization, new urbanization, agricultural modernization synchronous propulsion stage, seize the favorable opportunity, accelerate the promotion of information consumption, can effectively stimulate domestic demand, a new economic growth point of birth, and can improve and develop the service industry, promote economic restructuring and improving people's livelihood, is a both the current and long-term benefit and major initiatives, both steady growth and adjustable structure.

Promotion of the transformation of economic development mode and the adjustment of economic structure, vigorously develop the emerging service industry, change the backward situation of lack of customer service repair mode, home appliances and consumer information service industry personnel quality is not high and the talent training in China, Nanjing Communications Institute of Technology and Suning Appliance Limited by Share Ltd since 2010 to carry out school enterprise cooperation, the two sides signed a cooperation agreement, order form training after sale repair engineer talent, training system innovation in China home appliance repair after sale service personnel and information consumption.

\section{ANALYSIS OF THE CURRENT SITUATION OF CHINA'S HOME APPLIANCE REPAIR SERVICE PERSONNEL AND INFORMATION CONSUMPTION}

A. Consumer Services and Information Appliance Repair Shortage of Talent, the Quality Needs to be Improved

In recent years, the pace of development of the consumer goods market continues to accelerate, have been expanding, including home appliances and information consumption, expanding domestic demand and stabilize economic growth has made a positive contribution. Building a moderately prosperous society and improve people's livelihood, digital TV, mobile phones, computers, broadband networks have become essential goods have become home. Continued strong sales of home appliances market, which gives the consumer appliance repair and information services industry has brought tremendous market opportunities and challenges. However, China's home appliance repair and service information consumption shortage of talent, service enterprises are still in small, scattered, chaotic state, employing a lower level of education, to vocational school students or business, short-term training community-based training, tertiary IT classes Few graduates, holding senior workers accounted for only about $10 \%$ of the certificate. This situation with the current market demand for appliance repair service are incompatible. Low quality of employees, resulting in difficult to guarantee the quality of service, many appliances refresher rate is high, the maintenance staff to reap huge profits through fraudulent behavior not uncommon in the maintenance market, "fuss" has become the industry's unspoken rules, consumer those interests are not protected. Rural and remote areas than in urban household appliances repair services more difficult, less service outlets in these areas, maintenance personnel missing, even in many rural areas are still facing find repair outlets or maintenance personnel will not repair the situation. With such a huge market size and needs, school-enterprise cooperation in order training Repairs talented engineers, universities and enterprises can give full play to the advantages of professional training for students and vocational skills training to improve consumer services and information appliance repair personnel training quality .

\section{B. Lack of a Unified Qualification Certification}

Current consumption of appliance repair and information services sector most employees did not participate in formal 
professional skills training, no qualification certificate, some provinces and information requirements of consumer appliance repair service personnel with qualification certificate, but the provinces fragmented, lacking a unified national practitioners accreditation. Maintenance companies do not want to participate in maintenance grading and maintenance companies why not pay attention to their degree of specialization? Many repair company official said, although aware of appliance repair needs to have work license, but due to recruitment difficulties, so recruit people, so long as appliance repair, is generally not required if the vocational qualification certificate, the new recruit employees no formal professional skills training directly to the posts. Consumer acceptance for service on repairs and maintenance business intelligence generally did not require that consumers should know that appliance repair personnel certificates, but if not, then as long as the repair Haojiu Hang. As most appliance repair personnel without qualification certificate, if insisting there is evidence, no one could appliance repaired.

\section{Appliance Repair Service Personnel Training System in Need of Reform}

With the upgrading of information products, home appliances, big-screen 3D LCD TV, smart phones, laptop computers, digital cameras, home appliances cameras and other information products colorful range of emerging market, broadband networks, cloud computing, wireless networks, and other family intelligent terminal development on the maintenance personnel and technical requirements are higher. At present, low maintenance staff qualifications, professional skills, professional quality and other aspects mainly the consumption of services in information professionals lack. For a long time, China's home appliance repair service in the industry, is the apprentice chef heritage system. With the upgrading of industries, home appliances, information tech content products continues to increase, those repairs "Old Master" technology has been behind the technology upgrade cycle, for the new electronic information products are often not read, can not repair, now By master train an apprentice teaching experience ways to cultivate talent appliance Repairs career path is a dead end.

Vocational schools by teachers, space, equipment and other conditions, is still a "classroom" which, personnel training system that no longer meet the emerging service requirements for professionals. Without school-enterprise cooperation, students do not have the opportunity to practice and training and corporate internships, the end result is not learned through theory, technology and no master. Graduates difficult to competent appliance repair, information consumer services positions, the community does not recognize that the school's enrollment more difficult. Even many schools have closed a professional appliance repair schools only for some laid-off workers and migrant workers carry cell phones, computers and other simple maintenance skills training. Reform the traditional home appliance repair service personnel training system, universities and business cooperation contract training Appliance Repairs talented engineers to build a high level of business, excellent quality of service engineer personnel, to enable enterprises to gain the initiative in the market competition, improve market competitiveness force, quality of service and efficiency, improve the ability to absorb employment emerging services.

\section{SCHOOL-ENTERPRISE CO-CULTURED APPLIANCE REPAIR ENGINEER PERSONNEL PRACTICES}

\section{A. Both Schools and Enterprises Jointly Developed Training Plan}

College organized in cooperation with Suning Appliance " Suning Repairs engineer classes," title " Suning " class . " Suning " class from the School of Electronic Information Engineering College, communication technology, computer network technology Sophomores in merit, the participants after a year of work and study on-campus and off-campus practice and training professional training, complete the " Suning class" professional training learning and skills training courses, Suning Appliance Company in the third year of internship , after passing the examination , was hired as Suning Appliance Repairs engineer. Schools and businesses to discuss , develop personnel training programs, personnel training enterprises to participate in the whole process . Both schools and enterprises based on emerging service industry development and market demand to develop " Suning " class teaching program to develop professional courses, determine course objectives, choice of teaching content, the schools teach, students learn, companies used combine all three . Actively promote the professional curriculum standards and professional standards intermediation, education, vocational skills appraisal standards and assessment criteria of convergence. In the "Suning class" teaching plan, set smart phone repair, laptop repair, maintenance of flat-panel TVs , broadband network maintenance, corporate culture, employee behavior regulation, and other technical courses . Enterprises directly involved in the students' professional ethics, professionalism, professional business skills and employability, entrepreneurship training, planned for work and study, internships , training needed talent emerging service industries

\section{B. Give Full Play to the Advantages of Order Training Maintenance Engineers Talent}

And Suning Appliance cooperation and give full play to the enterprise information advantages, personnel, equipment, and space superiority, social order training needed appliance repair personnel. Enterprises have the latest market information, the partners according to new market information , employmentoriented to service for the purpose of joint research, the development of personnel training programs and teaching plan, organize professional training, to meet market demand. Gathered a large number of manufacturing companies, service line of practical and technical personnel and management personnel, who have extensive experience in management and skilled so that they can pass for students, to help with, it is effectively improve students' vocational skills and professional qualities key . Enterprise production workshop , shopping malls, facilities, equipment, practice base outside school as a student, to create a good environment for students to weekends, holidays can go to the training base for practice and training , before graduating to focus on integrated internships , and employment docking, with the prospective employee training docking, under the guidance of technical staff in the 
enterprise, the students mastered the consumer appliance repair and information services expertise, Suning Appliance employment after graduation and shorten the growing talent and run-in period

\section{Innovative Training System, Both Schools and Enterprises Win-win}

Innovative training system, business experts and technical personnel sent to the school to give lectures to the "Suning " classes teach students smartphone repair, laptop repair, maintenance of flat-panel TVs , broadband network maintenance, corporate culture, employee behavior regulation, and other technical courses. " Suning " trainees use weekends, holidays, vacation leave school to prospective employees' identities to each of Suning Appliance stores, outlets, maintenance, engineering and other departments for teaching practice, with the technical staff, the master to learn the knowledge and maintenance service skills before graduating to focus on comprehensive internships for new employee orientation, students experience the corporate vision and culture and to cultivate the spirit of dedication, the accumulation of experience in home appliance repair service information products. Not only effective solution to the current training model of appliance repair defects and improve the quality of personnel training, but also for enterprises to save the cost of human resources. Enterprises in the school of technology, equipment and venues provide support to solve the school technology is weak, inadequate training facilities and venues intense difficulties and enhance the school's educational strength and realize mutual school-enterprise cooperation, complementary advantages, mutual benefit .

\section{Promote Work-Study, Internship in an Orderly Manner}

Summer school-enterprise cooperation for college work-study , internship provided a guarantee. Suning Appliance Company accepts every summer arrangement " Suning class" students to the chain Suning Appliance, network management , maintenance department work-study, social practice and training ; 3 Year Arrangement "Suning class" students focus on internships . Suning Appliance aspects of work-study arrangements for students , internship positions, arrange technical staff and chef to give specific guidance, provide good logistical support, meal allowance paid on time and labor remuneration. Students participate in organized training base outside professional counterparts work-study, internship, centralized management, emerging service industries to encourage students to work, hard working, patient and meticulous service to consumers, in practice, to improve maintenance skills and professional qualities. Overcome the past work-study, internship and professional no connection to entertainment, restaurants earn money simply by physical disadvantages, to avoid some black intermediary engage fraud, corporate arbitrary deductions owed wages phenomenon, protect student personal safety and legitimate rights and interests, and promote the college summer work-study, internship healthy and orderly manner.

\section{E. Adapt to Industrial Transformation and Upgrading, Skills Training to Promote Employment}

"Long-term Education Reform and Development Plan," states: "employment-oriented, promoting school-enterprise cooperation, work and study, internships is to adapt to economic and social development, promoting employment of graduates to meet the needs of business professionals an effective way." Currently, one is the difficult employment of university graduates, on the other companies can not find a suitable application of high-skilled talents. Suning retail business from the traditional retail enterprises to upgrade to the Internet, the company changed its name to Suning Yun providers, "electricity providers ++ retail shops to service provider" is Suning Yun providers. In the process of transformation and upgrading, Suning master new technologies to create new models, create new platforms, create new groups, need to adapt to industrial transformation and upgrading of high-skill talents.

School-enterprise cooperation in order training appliance repair engineer talent, "Su Ning," Ban 3rd year student internships to Suning Yun providers, graduation practice and employment docking. Through internships exercise, the students mastered the appliance repair and Internet terminal services professional knowledge and skills, to participate in Skill Testing Center, Jiangsu Province, the unified organization of professional certification exams, obtain vocational qualification certificate, after being hired as Suning Yun qualified supplier Repairs engineer, to meet China's industrial structure optimization and upgrading of industrial development and emerging service needs, improve the ability to absorb employment services, to solve the difficult employment of college graduates in computer science problems for students needy families share those problem-solving, is conducive to social harmony and stability and development.

\section{SCHOOL-ENTERPRISE COOPERATION IN PERSONNEL TRAINING ORDERS PROBLEMS AND SUGGESTIONS}

\section{A. Optimize the Curriculum System, Improve Service} Optimization and Upgrading of Industrial Capacity

Through the "Suning class" follow-up survey, held a " Suning class " student forum , I learned "Suning class" Curriculum System of the corporate culture, service businesses, employees and other courses are more standardized, energy saving appliances new technologies, Internet, smart terminal class information consumer services courses less. In the implementation of " Suning " class teaching plans, corporate culture, corporate employees norms curriculum lessons more relevant energy-saving appliances, information appliances of new products, new processes, new technology, professional curriculum hours less, such as LCD flat television, broadband network security and maintenance, repair fault detection smartphone standard processes , etc., students eager to learn more energy-saving appliances , information appliances of new technologies and new knowledge . Schools and cooperative enterprises through discussion, optimizing curriculum, adjust their teaching programs to strengthen environmental protection and new energy-saving appliances, security and maintenance of broadband networks, laptops, smart phones repair, Internet retail and other aspects of professional courses, targeted training appliance repair system consumer services and 
information of high skilled personnel, improve service industrial optimization and upgrading of skills.

\section{B. School-Enterprise Cooperation to Establish Coordination and Communication Mechanisms to Strengthen the Guidance and Management Internships}

The college has school-enterprise cooperation office, and Department of the Ministry is not the person responsible for school-enterprise cooperation and internship management, school-enterprise cooperation lack of appropriate coordination and communication mechanisms, which restricts the school-enterprise cooperation work in depth, which is currently the school school-enterprise cooperation widespread problem. If according to industry characteristics, Suning Yun provider organization "Suning class" students to participate in large scale during the holidays after-sale technical service activities, since the lack of coordination and communication in advance, sometimes in conflict with the school curriculum, on-campus courses affect student learning. If the school office and the school-enterprise cooperation in advance Department of the Ministry in coordination with the relevant authorities beforehand Suning Appliance to communicate, make adjustments and arrangements to avoid the above-mentioned phenomenon.

Students in the school post internship, schools and cooperative enterprises less contact and communication, lack of macroeconomic management and guidance, not timely and businesses to understand and communicate student internships, unable to timely detection of problems and coordinate and solve problems. Proposals to strengthen the guidance and management internships, establish a regular inspection and inspection system, to strengthen business linkages and cooperation and communication, department a person responsible for internship management, timely understanding and communication to the business students internships situation, to help enterprises solve Dinggang internship practical problems.

\section{Overcome the Simple Pursuit of Economic Phenomena, and Establish Long-Term Personnel Training Concept}

Business from their own interests, the pursuit of economic efficiency, investment in human resources and training, lack of long-term concept. Suning Yun trader in arranging student internships, a shortage of staff in the season when sales customer service practices assigned students to do more projects, arranging computers, mobile phones, electronic products and other maintenance practices fewer projects, practical projects and time allocation is not reasonable students cannot have planned learning skills in various positions, students do not have more exposure to energy saving appliances and information appliances, new technologies, the students learn to master a more comprehensive variety of electrical maintenance techniques affected. Cooperative enterprises should overcome the simple pursuit of economic phenomena, and establish a long-term concept of personnel training, internships planned rotation exercise, to create more opportunities to expose students to a variety of home appliances new products, new technologies, to enable students to fully grasp the appliance repair and information consumption service skills in various positions, as quickly as possible for the modern service industry in emerging high-skilled personnel.

\section{Develop Incentive Policies to Encourage Enterprises under the Guidance of Teacher Training}

Enterprises under the guidance of teachers to students' internships and professional competence of teachers demanding a great responsibility, hard work. Enterprises under the guidance of faculty workload calculation internship lack supporting incentives, rewards often not as taught in schools and in schools with training courses and more teachers teaching in schools undertake more work, and thus teachers to students off-campus internships guidance only could be payable. Instructor just by phone, online or an internship internship visits to understand the situation, usually on the "Suning class" student internships less specific guidance with the personnel department, instructor lack of communication and for communication, internship guidance and management over more dependent on business. Advised the College introduced teachers to the next business practicum supporting incentives to mobilize teachers enterprises under guidance internship enthusiasm for student internships give more to specific guidance, with the personnel department, instructor timely exchange and configuration pass, can be solved in student internships in problems.

\section{E. Appliance Repair and Information to Improve Consumer Services Staff conditions and Wages}

Appliance repair service personnel and information consumption is particularly arduous working conditions, should always be TV, cell phones and other electronic products, electromagnetic radiation, to do service in the summer heat but also endure heat, coupled with the intensity of work in this industry is quite large, standardized, standardization and fewer specialized service companies, so that maintenance personnel practitioners no environmental protection. Few students now have the older sense of spirit, many students fear of hardship, so the consumer services and information appliance repair work is not welcomed by the students . The current consumption of appliance repair and information services industry has a " low-income, highpaying ", and learned in the investigation , many practitioners to be a lot of work every day, the average monthly wage of employees in Nanjing area of about 3,400 yuan monthly salary is rarely exceed $\$ 4,000$, which is a large gap between the expectations of a new generation of talent, new entrants to the industry in recent years, college students have too low pay drain phenomenon. Therefore, to avoid brain drain is related enterprises should attach importance to solve this problem is to have business for institutional reform and innovation, should increase investment in order to improve consumer information appliance repair and service staff working conditions and wages, salary increase and increase the attractiveness of the industry and retain talent. Also implement some reward system is also very necessary, motivate maintenance personnel self-learning, improve their technical level, the service quality is improved, very impressive for the enterprise 's interests. 


\section{CONCLUSION}

Countries to actively encourage and promote home appliances and information consumption, the birth of a new economic growth point, improving people's livelihood, introduced a series of new policies. In the New Deal stimulated the formation of purchasing energy-saving appliances and information consumption boom, which the consumer appliance maintenance services and information put forward higher requirements. School-enterprise cooperation in order training, after-sales maintenance engineer personnel, can effectively solve my new state of modern service industry personnel training system behind the shortage of highly skilled personnel, the quality of employees is not high status, improve .

Appliance Repairs, service quality and consumer information level. Speed train high-quality services for the modern emerging high-skilled personnel, consumer confidence, satisfaction and improve the quality of life of urban and rural residents.

\section{ACKNOWLEDGEMENT}

This article for the Higher Education Institute of Jiangsu province "1025" planning project supported by the scientific research in Higher Education "school enterprise cooperation training research and practice of customer service repair engineer mode" (project number: KT2011002; host: Xing Jiangyong) one of the initial results.

\section{REFERENCES}

[1] State Council on the promotion of information consumption to expand domestic demand, a number of opinions [Z]. August 2013.

[2] Lu Xin, Vice Minister of Education Lu Xin, 2012 Vocational Education and Adult Education Conference Speech [Z]. March 2012.

[3] Yang Mingxiang, appliance repair service management study [J] Market Modernization, August 2010 (on Xunkan) 28-29.

[4] Li Meihua Wang Jianwei, "the two group complementary" vocational training base construction research and Practice for $[\mathrm{J}]$. Vocational Education Forum, 2012 June, 28 - 29.

[5] Zhou Jianliang, electronic professional training base connotation construction strategy and implementation [J]. Jilin Education, October 2010, 29.

[6] Xing jiangyong Baowei Nanjing appliance repair service personnel needs survey and analysis [J]. Commercial Times, April 2013,170-171. 